\title{
Can previous treatment with beta-blockers attenuate myocardial dysfunction in patients with Tako-Tsubo cardiomyopathy?
}

\section{Jure Samardžić* \\ Marijan Pašalić \\ Željko Baričević \\ Hrvoje Jurin \\ Maja Čikeš \\ Davor Miličić}

University of Zagreb

School of Medicine,

University Hospital Centre

Zagreb, Zagreb, Croatia
RECEIVED:

April 15, 2015

ACCEPTED:

April 20, 2015
KEYWORDS: Tako-Tsubo cardiomyopathy, myocardial disease, beta-blockers. CITATION: Cardiol Croat. 2015;10(3-4):67. | DOI: http://dx.doi.org/10.15836/ccar.2015.67

ORCID: Jure Samardžić, http://orcid.org/0000-0002-9346-6402 • Marijan Pašalić, http://orcid.org/0000-0002-3197-2190 • Željko Baričević, http://orcid.org/0000-0002-5420-2324 • Hrvoje Jurin, http://orcid.org/0000-0002-2599-553X • Maja Čikeš, http://orcid.org/0000-0002-4772-5549 • Davor Miličić, http://orcid.org/0000-0001-9101-1570

*ADDRESS FOR CORRESPONDENCE: Jure Samardžić, Klinički bolnički centar Zagreb, Kišpatićeva 12, HR-10000 Zagreb, Croatia. Phone: +385-98-537864. E-mail: jure.samardzic@gmail.com

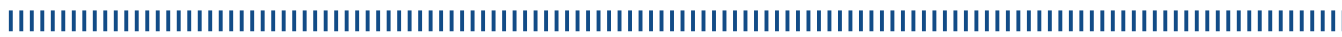

INTRODUCTION: Tako-Tsubo cardiomyopathy (TTC) is a clinical condition characterized by acute and generally reversible myocardial dysfunction. It is usually triggered by significant emotional or physical stress. Catecholamine activation of adrenoceptors has been recognized as a primary trigger of pathophysiological changes in TTC.1. Previous data showed no evidence that cardioprotective drugs such as beta-blockers (BB) decrease reoccurrence of $\mathrm{TTC}^{2}$. We sought to evaluate whether chronic BB therapy attenuates myocardial dysfunction and type of wall motion abnormalities (WMA) in patients presenting with TTC.

METHODS: We retrospectively analyzed medical record data of patients admitted with TTC from January 2011 to March 2015. Left ventricular ejection fraction (LVEF), location and extent of MWA were compared between patients previously treated with $\mathrm{BB}$ and patients without a BB in therapy at admission.

RESULTS: Twenty-one patient with TTC was identified. Nine patients were BB users and eleven patients were BB non-users. Information on previous BB therapy was not available for one patient who was excluded from the analysis. There was no significant differences in demographic and clinical data between study groups. No statistically significant difference in LVEF and forms of WMA was found between study groups ( 0.425 and 1.000 , respectively) (Table 1)

CONCLUSION: Results indicate that previous use of BB does not attenuate the severity of myocardial dysfunction nor the type of WMA in patients presenting with TTC. These results warrant further investigation and confirmation on a larger number of patients. Time of patient presentation and echocardiographic examination should also be considered in the analysis.

TABLE 1. Patients' data.

\begin{tabular}{lccc}
\hline & BB users (N=9) & BB non-users (N=11) & $p$ \\
\hline Age, mean (min-max) & $63.56(33-79)$ & $60.09(45-76)$ & 0.617 \\
\hline Women, $n$ & 8 & 7 & 0.319 \\
\hline Type of WMA, n & 5 & 6 & 1.000 \\
apical & 4 & 5 & \\
apical and midventricular & 0 & 0 & \\
midventricular & 0 & 0 & 0.425 \\
basal & $47.22(14.1)$ & $42.27(12.9)$ & \\
\hline LVEF, mean (SD) & & &
\end{tabular}

BB - beta-blocker; LVEF - left ventricular ejection fraction; SD - standard deviation; WMA - wall motion abnormality

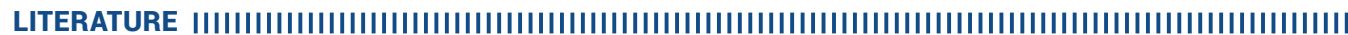

1. Wittstein IS, Thiemann DR, Lima JA, Baughman KL, Schulman SP, Gerstenblith G, et al. Neurohumoral features of myocardial stunning due to sudden emotional stress. N Engl J Med. 2005;352:539-48. DOI: http://dx.doi.org/10.1056/NEJMoa043046

2. Sharkey SW, Windenburg DC, Lesser JR, Maron MS, Hauser RG, Lesser JN, et al. Natural history and expansive clinical profile of stress (tako-tsubo) cardiomyopathy. J Am Coll Cardiol. 2010; 55:333-41. DOI: http://dx.doi.org/10.1016/j.jacc.2009.08.057 